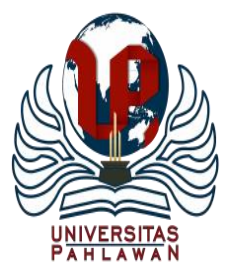

Edukatif : Jurnal Ilmu Pendidikan Volume 3 Nomor 5 Tahun 2021 Halm 2854 - 2860

EDUKATIF: JURNAL ILMU PENDIDIKAN

Research \& Learning in Education

https://edukatif.org/index.php/edukatif/index

\title{
Penggunaan Media Pembelajran Wordwall untuk Meningkatkan Minat dan Motivasi Belajar Siswa pada Pembelajaran Tematik di Sekolah Dasar
}

\author{
Siti Faizatun Nissa ${ }^{1 凶}$, Novida Renoningtyas ${ }^{2}$ \\ Pendidikan Guru Madrasah Ibtidaiyah, IAIN Salatiga, Indonesia ${ }^{1,2}$ \\ E-mail : sitifaizatunnissa@gmail.com ${ }^{1}$, novidanovie03@ gmail.com ${ }^{2}$
}

\begin{abstract}
Abstrak
Pandemi Covid-19 membuat lembaga pendidikan di Indonesia, termasuk SDN Suniarsih melakukan pembelajaran daring menggunakan media wordwall untuk membantu siswa dalam memahami materi pada pembelajaran tematik. Tujuan penelitian ini yaitu untuk mengetahui bagaimana penggunaan media wordwall pada pembelajaran tematik kelas II di masa pandemi covid-19. Metode yang digunakan pada penelitian ini yaitu kualitatif dengan metode wawancara dan observasi. Wawancara dilakukan guna menggali informasi terkait penggunaan wordwall, sedangkan observasi dilakukan untuk mengamati secara langsung pelaksanaan penggunaan media wordwall. Hasil penelitian menunjukkan bahwa adanya perubahan sikap yang terjadi pada siswa setelah dilakukannya pembelajaran dengan menggunakan media wordwal. Perubahan tersebut dapat dilihat dari aspek keaktifan siswa serta kriteria penilaian observasi diukur melalui beberapa indikator, antara lain yaitu: (a) Keaktifan siswa saat mengikuti kegiatan belajar mengajar secara daring (online) dibuktikan dengan pengisian absen, (b) Keaktifan siswa saat mengumpulan tugas dengan tepat waktu, (c) Bertanya terhadap materi yang belum dipahami. Kesimpulan dari penelitian ini bahwa penggunaan media wordwall pada pembelajaran tematik kelas II mampu meningkatkan minat dan motivasi belajar siswa.
\end{abstract}

Kata Kunci : Wordwall, Covid-19.

\section{Abstract}

The Covid-19 pandemic has forced educational institutions in Indonesia, including SDN Suniarsih, to conduct online learning using wordwall media to help students understand the material in thematic learning. The purpose of this study is to find out how to use wordwall media in class II thematic learning during the covid-19 pandemic. The method used in this research is qualitative with interview and observation methods. Interviews were conducted to explore information related to the use of wordwalls, while observations were made to observe directly the implementation of the use of wordwall media. The results showed that there was a change in attitude that occurred in students after learning by using wordwal media. These changes can be seen from the aspect of student activity and the observation assessment criteria are measured through several indicators, including: (a) The activeness of students when participating in online teaching and learning activities as evidenced by filling in absences, (b) Student activity when collecting assignments by on time, (c) Asking about material that has not been understood. The conclusion of this study is that the use of wordwall media in thematic learning of class II can increase students' interest and motivation in learning.

Keywords: Wordwall, Covid-19.

1

Copyright (c) 2021 Siti Faizatun Nissa, Novida Renoningtyas

$\triangle$ Corresponding author

Email : sitifaizatunnissa@gmail.com

DOI : https://doi.org/10.31004/edukatif.v3i5.880

ISSN 2656-8063 (Media Cetak)

ISSN 2656-8071 (Media Online)

Edukatif : Jurnal Ilmu Pendidikan Vol 3 No 5 Tahun 2021 p-ISSN 2656-8063 e-ISSN 2656-8071 
2855 Penggunaan Media Pembelajaran Wordwall untuk Meniongkatkan Minat dan Motivasi Belajar Siswa pada Pembelajaran Tematik di Sekolah Dasar-Aulia Diana Devi, Subiyantoro

DOI : https://doi.org/10.31004/edukatif.v3i5.880

\section{PENDAHULUAN}

Pandemi Covid-19 (Rohayani, 2020) merupakan masalah utama dalam bidang kesehatan yang saat ini tengah menjadi sorotan di dunia. Pengaruh Covid-19 berdampak pada hampir semua aspek kehidupan karena adanya pembatasan sosial dari pemerintah guna menekan penyebaran Covid-19 (I. K. Sari et al., 2021). Adanya pandemi ini memaksa masyarakat melakukan hal-hal baru yang belum pernah mereka lakukan seperti, menutup bandara (yang jarang sekali dilakukan, kecuali dalam keadaan daruat), menutup toko-toko hingga sekolah. Penutupan sekolah ini mulai dari jenjang sekolah dasar hingga perguruan tinggi. Selain itu, masyarakat juga diminta untuk melakukan WFH (Work from Home) selama pandemi Covid-19. Tidak hanya Indonesia yang mengambil kebijakan tersebut (Saleh, 2020), banyak pula negara-negara didunia yang melakukan hal serupa untuk menekan penyebaran covid-19. Penutupan lembaga pendidikan tersebut kemudian dialihkan pada pembelajaran yang dilakakan dari rumah (online).

Surat Edaran Nomor 4 Tahun 2020 tentang Pelaksanaan Pendidikan Masa Darurat Penyebaran Corono Virus Desease 2019 (Covid-19) yang dikeluarkan oleh Kementerian Pendidikan dan Kebudayaan Republik Indonesia, menetapkan bahwa pembelajaran yang semula dilakukan secara tatap muka (offline) kini dialikan menjadi BDR (Belajar dari Rumah). Pembelajaran dari rumah ini dilakukan dengan moda daring (dalam jaringan) (Saleh, 2020). Model pembelajaran daring merupakan pembelajaran mandiri yang dilakukan secara online melalui aplikasi pembelajaran maupun jejaring sosial. Model pembelajaran daring sangatlah berbeda dengan model pembelajaran tatap muka. Aktivitas belajar yang dijumpai pada saat pembelajaran daring antara lain seperti : pembelajaran mandiri dari informasi yang diperoleh dari dokumen daring, latihan daring, tugas daring, pencarian materi pembelajaran individual dan lain sebagainya (Anggrawan, 2019). Peserta didik yang biasanya belajar secara langsung dengan guru, kini harus belajar melalui daring.

Kurangnya penguasaan terhadap teknologi bagi guru dan siswa, kurang memadainya sarana prasarana, menjadi masalah tersendiri (Syah, 2020). Suhardi et al., (2021) menyatakan bahwa pembelajaran dengan moda daring menuntut guru untuk lebih kreatif serta orang tua yang harus ikut berkontribusi dalam mendampingi anak-anaknya belajar. Senada dengan Atsani (2020), dalam menyampaikan materi pembelajaran melalui daring, yang dalam hal ini juga harus disesuaikan dengan jenjang pendidikan serta kebutuhan siswa. Guru perlu memiliki pola pikir yang positif sehingga memunculkan solusi yang kreatif guna penyampaian materi melalui daring, dengan ini capaian pembelajaran yang dihasilkan akan tersampaikan dengan baik dan berkualitas.

Jenjang sekolah dasar menggunakan Kurikulum 2013 dengan pendekatan tematik. Pembelajaran dengan pendekatan tematik merupakan pembelajaran yang mengaitkan beberapa mata pelajaran kedalam sebuah tema, dengan pembelajaran ini siswa menjadi lebih mudah dalam memahami konsep (Wahyuni et al., 2016). Guru perlu menyiapkan buku-buku maupun bahan pembelajaran lain yang berhubungan dengan tema yang dipelajari (Inderasari \& Agustina, 2017). Guru perlu menyiapkan media pembelajaran guna mendukung penyampaian materi pelajaran (Wahyuni et al., 2016), serta merancang dan mendesain sebuah media pembelajaran yang dapat menghidupkan suasana KBM yang disesuaikan dengan adanya kebutuhan siswa (Hae \& Rezeki Patricia Tantu, 2021).

Selain itu, pada masa pandemi ini guru dan siswa membutuhkan sebuah media/alat komunikasi yang dapat digunakan untuk melakukan pembelajaran secara daring seperti, gadget, laptop atau komputer yang dapat tersambung dengan jaringan internet (Rahma et al., 2021), seperti yang tercantum dalam SE No 15 tahun 2020 (Kemendikbud, 2020) bahwa media yang dapat digunakan untuk pembelajaran daring yaitu bisa menggunakan laptop, gadget, aplikasi pembelajaran, video pembelajaran, dll. Guru perlu menggunakan dan memilih media pembelajaran yang interaktif agar materi yang disampaikan dapat diterima dengan mudah oleh siswa, serta sesuai dengan tujuan pembelajaran yang akan dicapai. 
2856 Penggunaan Media Pembelajaran Wordwall untuk Meniongkatkan Minat dan Motivasi Belajar Siswa pada Pembelajaran Tematik di Sekolah Dasar-Aulia Diana Devi, Subiyantoro

DOI : https://doi.org/10.31004/edukatif.v3i5.880

Tetapi pada kenyataannya banyak guru yang masih kesulitan dalam membuat media pembelajaran berbasis IT dalam pelaksanaan pembelajaran tematik. Kesulitan yang dialami para pendidik dikarenakan kurangnya pengetahuan terhadap pembuatan media pembelajaran berbasis IT, sehingga banyak dari mereka yang hanya memanfaatkan buku tema sebagai bahan ajar utama dalam proses pembelajaran daring saat ini. Hal ini senada dengan (Pranata et al., 2021) yang menyatakan bahwa penyebab kurangnya minat belajar siswa adalah kurangnya kompetensi guru dalam memanfaatkan teknologi, serta media pembelajaran yang digunakan sangat terbatas. Proses pembelajaran yang kurang menyenangkan akan menjadikan anak malas dan kurang bersemangat dalam mengikuti pembelajaran daring. Media pembelajaran yang mudah untuk dibuat tentunya akan sangat diperlukan guru saat ini, agar dalam pembuatannya tidak memerlukan waktu yang lama dan mudah untuk dibuat dan digunakan. Hal tersebut membuat peran guru bukan hanya menyampaikan materi pelajaran saja, namun guru juga mampu memanfaatkan teknologi menjadi sebuah media pembelajaran (One, 2017).

Rendahnya minat dan motivasi pada diri siswa akan sangat berpengaruh terhadap prestasi belajar siswa, untuk itu perlu adanya inovasi yang dilakukan guru dalam pembuatan media pembelajaran, sehingga masalah dan kesulitan yang dialami saat ini dapat segera diatasi. Media pembelajaran interaktif sangat dibutuhkan sebagai solusi dalam permasalahan ini. Sebuah media pembelajaran yang dapat mudah untuk digunakan oleh siapapun,untuk itu peneliti tertarik untuk melaksanakan sebuah penelitian terkait media pembelajaran interaktif yang dapat digunakan dalam pembelajaran tematik kelas II.

Salah satu media pembelajaran interaktif yang dapat digunakan yaitu wordwall, seperti yang diungkapkan (Maghfiroh, 2018) dalam penelitiannya, bahwa media wordwall mampu menciptakan interaksi yang menguntungkan bagi siswa. Wordwall (P. M. Sari \& Yarza, 2021) merupakan salah satu aplikasi yang bisa digunakan sebagai media belajar maupun alat penilaian yang menarik bagi siswa dalam pembelajaran daring. Beberapa kelebihan wordwall yaitu free untuk pilihan basic dengan pilihan beberapa template. Selain itu, permainan yang telah dibuat dapat dikirimkan secara langsung melalui whatsapp, google classroom, maupun yang lainnya. Software ini menawarkan banyak jenis permainan seperti, crossword, quiz, random cards (kartu acak) dan masih banyak lainnya. Kelebihan lainnya yaitu, permainan yang telah dibuat bisa dicetak dalam bentuk PDF, jadi akan memudahkan bagi siswa yang mempunyai kendala pada jaringan. Sejalan dengan Putri (2020), yang menyatakan bahwa wordwall dapat memudahkan siswa memahami materi pelajaran melalui daring, serta mudah digunakan guna mengetahui bagaimana prestasi belajar siswa. Tujuan dari penelitian ini adalah untuk mengetahui bagaimana penggunaan media wordwall pada pembelajaran tematik kelas II di masa pandemi covid.

\section{METODE PENELITIAN}

Penelitian ini merupakan penelitian kualitatif dengan metode observasi dan wawancara. Observasi digunakan untuk mengamati secara langsung kegiatan pembelajaran mengenai penggunaan media pembelajaran wordwall pada pembelajaran tematik pada masa pandemi covid-19. Sedangkan metode wawancara digunakan untuk menggali informasi tentangmedia pembelajaran wordwall pada pembelajaran tematik.

Penelitian ini dilakukan di SDN Suniarsih Kabupaten Tegal, dengan jangka waktu penelitian selama 1 minggu Subjek penelitiannya yaitu siswa kelas II SDN Suniarsih, sedangkan kepala sekolah, guru kelas II dan beberapa siswa sebagai informan untuk mendukung perolehan data observasi dan wawancara. Data yang diperoleh dari observasi dan wawancara tersebut selanjutnya dinarasikan untuk memperoleh gambaran umum mengenai media pembelajaran wordwall pada pembelajaran tematik kelas II SD N Suniarsih pada masa pandemi covid-19. 
2857 Penggunaan Media Pembelajaran Wordwall untuk Meniongkatkan Minat dan Motivasi Belajar Siswa pada Pembelajaran Tematik di Sekolah Dasar-Aulia Diana Devi, Subiyantoro

DOI : https://doi.org/10.31004/edukatif.v3i5.880

\section{HASIL DAN PEMBAHASAN PENELITIAN}

Penyebaran virus corona yang begitu cepat dan meluas menyebabkan beberapa sekolah yang ada di Indonesia harus melakukan pembelajaran jarak jauh atau online. Begitu juga di SDN Suniarsih, yang juga harus melakukan pembelajaran secara daring. Adanya pembelajaran daring ini membuat guru harus mampu dan bersiap untuk bertransformasi terhadap media pembelajaran.

Dari hasil observasi dan wawancara yang peneliti lakukan terhadap pembelajaran tematik kelas II di SDN Suniarsih, terlihat bahwa siswa sudah merasa bosan dengan proses pembelajaran daring yang sudah berlangsung sekitar satu tahun terakhir. Terlihat dari malasnya siswa dalam mengisi kolom presensi dan terlambatnya siswa dalam mengumpulkan tugas harian ataupun ulangan.

Rasa bosan akan sesuatu yang monoton bisa saja terjadi kapanpun dan dimanapun. Oleh karena itu berkreasi dan berinovasi dalam media pembelajaran perlu dilakukan guna menumbuhkan minat dan motivasi pada diri siswa. Ketika siswa mulai terlihat kehilangan semangat dan motivasinya dalam belajar apalagi pada masa pandemi seperti ini, maka tugas pendidik harus mampu mengembalikan minat dan motivasi anak didik. Salah satu yang bisa kita lakukan adalah dengan menggunakan media pembelajaran yang bervariasi.

Hasil observasi peneliti, media yang digunakan oleh guru kelas II SDN Suniarsih pada pembelajaran tematik dimasa pandemi yaitu menggunakan wordwall. Wordwall (Sherianto, 2020) merupakan aplikasi yang bisa dijadikan sebagai media belajar, sumber belajar, serta alat penilaian bagi guru dan siswa. Wordwall juga menyediakan beberapa contoh hasil kreasi guru yang dapat membantu pengguna baru dalam berkreasi.Media pembelajaran ini (Halik, 2021) juga dapat diartikan web aplikasi yang digunakan untuk membuat games berbasis kuis yang menyenangkan. Selain itu, wordwall juga dapat digunakan untuk merancang serta mereview penilain dalam pembelajaran.

Adapun langkah-langkah yang dapat digunakan untuk dapat menggunakan aplikasi Wordwall yaitu : 1) Tentunya agar kita dapat menggunakan aplikasi ini sebagai salah satu media dalam pembelajaran tematik, langkah awal yang harus kita lakukan adalah membuat atau mendaftarkan akun di https;//wordwall.net kemudian lengkapilah data yang tertera didalamnya, 2) Pilihlah create activity lalu pilihlah salah satu template yang ada, 3) Tuliskanlah judul dan deskripsi permainan, 4) Tulislah konten yang diinginkan sesuai dengan tipe permainan yang diinginkan, 5) Pilih done, sebagai langkah akhir jika kita sudah selesai membuatnya.

Berikut merupakan salah satu contoh penggunaan media wordwall pada pembelajaran tematik kelas II, yang di gunakan pada saat pembelajaran daring tema 8 keselamatan di rumah dan diperjalanansubtema I aturan keselamatan di rumah. Dimana guru kelas II menyiapkan bahan ajar yang kemudian diterapkan dalam sebuah media pembelajaran dan kemudian disebarkan dan digunakan untuk pembelajaran anak. Adapun langkah-langkah yang digunakan adalah sebagai berikut :

Setelah guru menyapa dan mengawali pembelajaran pada WA grup, kemudian guru menyampaikan tujuan dan mengarahkan pembelajaran yang akan dilakukan. Setelah itu guru meminta siswa untuk membuka link yang sudah dibuat, dengan menuliskan nama kemudian start.

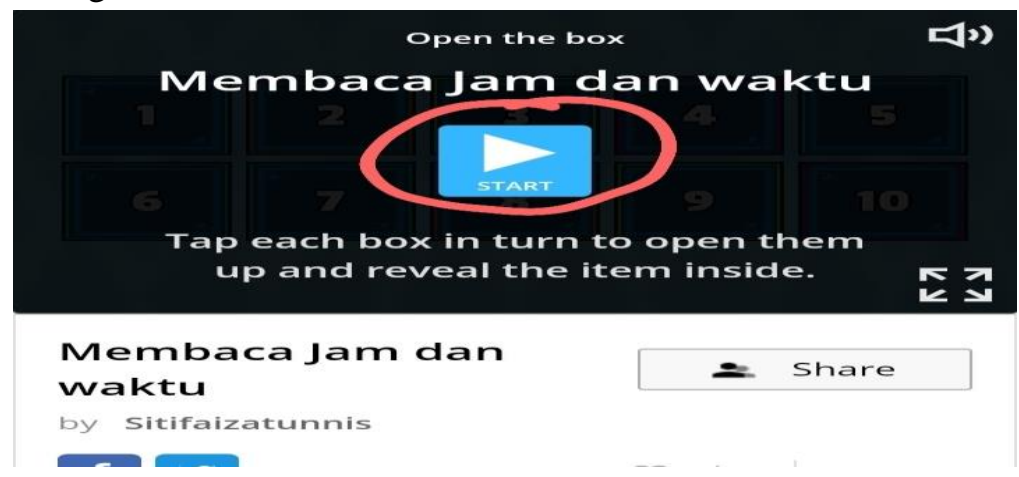

Gambar 1: Tampilan awal 
2858 Penggunaan Media Pembelajaran Wordwall untuk Meniongkatkan Minat dan Motivasi Belajar Siswa pada Pembelajaran Tematik di Sekolah Dasar-Aulia Diana Devi, Subiyantoro

DOI : https://doi.org/10.31004/edukatif.v3i5.880

Siswa mengisi sesuai perintah pertanyaan dengan timer yang terus berjalan.

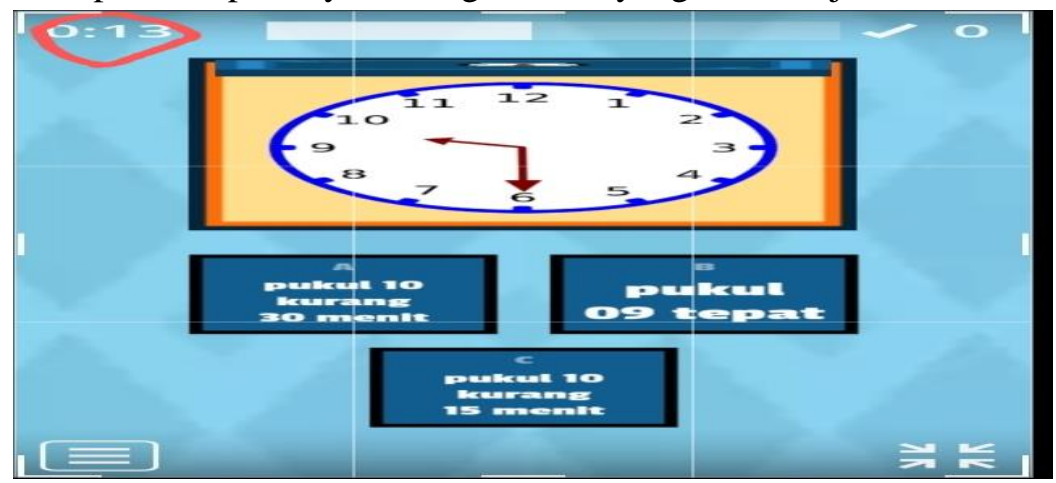

Gambar 2: Menu

Jika masih banyak yang salah dalam mengerjakannya bisa dicoba ulang dengan klik start again.

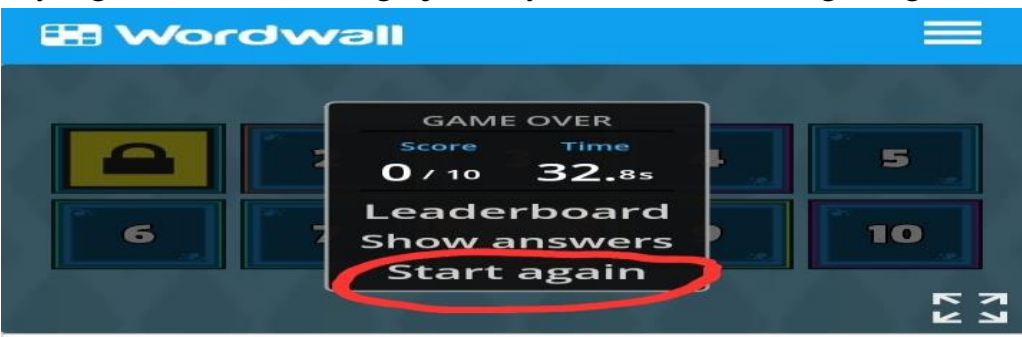

Membaca Jam dan

waktu

by sitifaizatunnis

$+$

Gambar 3: Tampilan untuk pengerjuaan ulang

Kita bisa melihat score yang dimaksud dengan timernya

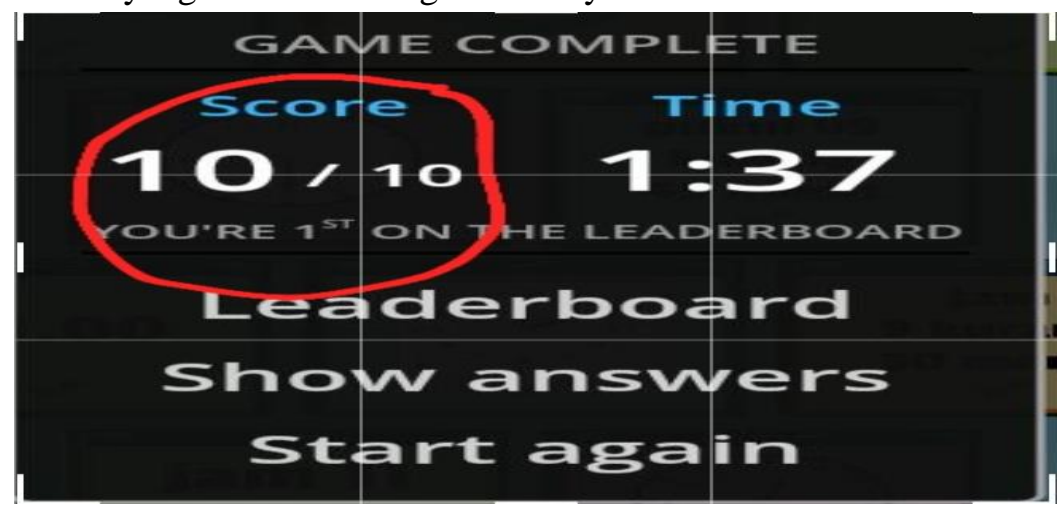

Gambar 4: Tampilan score yang diperoleh

Untuk melihat rekapan peserta didik yang mengerjakan berikut score dan timernya kita bisa buka wordwallnya, klik di my result. Disana akan terlihat siapa saja yang mengerjakan dan nilai/score serta waktu dalam mengerjakannya.

Hasil dari penggunaan media ini yaitu, bahwa media wordwall mampu meningkatkan minat belajar siswa. Hal tersebut dapat dilihat dari aspek keaktifan siswa, kriteria penilaian observasi diukur melalui beberapa indikator, antara lain yaitu: (a) Keaktifan siswa saat mengikuti kegiatan belajar mengajar secara daring (online) dibuktikan dengan pengisian absen, (b) Keaktifan siswa saat mengumpulan tugas dengan tepat waktu, (c) Bertanya terhadap materi yang belum dipahami. Keadaan tersebut jelas berbeda dengan proses pembelajaran daring jika guru hanya memberikan perintah kepada anak untuk membaca atau meresum. Ataupun guru hanya menyuruh anak untuk mencatat ulang materi yang ada pada buku tema. Berdasarkan hal tersebut, dapat terlihat bahwa setelah menggunakan media wordwall minat dan motivasi anak meningkat, 
2859 Penggunaan Media Pembelajaran Wordwall untuk Meniongkatkan Minat dan Motivasi Belajar Siswa pada Pembelajaran Tematik di Sekolah Dasar-Aulia Diana Devi, Subiyantoro

DOI : https://doi.org/10.31004/edukatif.v3i5.880

terlihat dari sikap anak yang mau bertanya di grup whatshap jika mengalami kesulitan dalam menjawab soal, aktifnya anak dalam mengisi presensi harian dan juga terlihat keaktifan siswa saat mengumpulan tugas. Senada dengan Azizah (2020), dalam penelitiannya yang menyatakan bahwa penguunaan media wordwall mampu meningkatkan penguasaan siswa terhadap kosa kata pada mata pelajaran bahasa arab. Selain itu, dalam penelitian (Bachry et al., n.d.) juga menyatakan bahwa media wordwall dapat meningkatkan kemampuan tegak bersambung pada siswa tunarungu.

Penelitian ini terbatas pada materi yang digunakan serta media yang dipakai untuk mengolah materi. Penelitian ini dapat mejadi tolak ukur dan menjadi salah satu sumber pengetahuan terkait media yang dapat digunakan oleh pendidik lain dalam mengajarkan tematik kelas II. Selain itu, penelitian ini dapat dijadikan sebagai salah satu sumber referensi bagi peneliti yang akan datang.

\section{KESIMPULAN}

Media pembelajaran wordwall merupakan salah satu media interaktif yang mudah untuk digunakan, serta dapat meningkatkan minat dan motivasi belajar siswa pada pembelajaran tematik kelas II. Media pembelajaran wordwall dapat dijadikan sebagai salah satu media yang digunakan dalam pembelajaran daring seperti saat ini. Selain penggunaan yang mudah dan murah, media ini juga memiliki banyak alternatif pilihan dalam menyajikan materi dan soal. Sehingga para pendidik dapat menggunakan pilihan alternatif lainnya sebagai variasi lain dalam mengemas materi pelajaran yang lain. media yang menyenangkan dan bervariasi akan membuat siswa lebih aktif dan lebih termotivasi dalam mengikuti proses pembelajaran daring.

\section{UCAPAN TERIMA KASIH}

Terima kasih kami ucapkan kepada Kepala SDN Suniarsih yang telah mengijinkan kami melakukan penelitian di SDN Suniarsih. Terima kasih pula kami ucapkan kepada guru kelas dan siswa-siswi kelas II SDN Suniarsih yang telah membantu dalam kelancaran proses penelitian, sehingga penelitian ini dapat berjalan dengan lancar.

\section{DAFTAR PUSTAKA}

Anggrawan, A. (2019). Analisis Deskriptif Hasil Belajar Pembelajaran Tatap Muka Dan Pembelajaran Online Menurut Gaya Belajar Mahasiswa. Matrik: Jurnal Manajemen, Teknik Informatika Dan Rekayasa Komputer, 18(2), 339-346. Https://Doi.Org/10.30812/Matrik.V18i2.411

Atsani, L. G. M. Z. (2020). Transformasi Media Pembelajaran Pada Masa Pandemi Covid-19. Jurnal Teknologi Pendidikan, 22(1), 65-70. Http://Journal.Unj.Ac.Id/Unj/Index.Php/Jtp

Azizah, H. N. (2020). Peningkatan Penguasaan Kosakata Bahasa Arab Melalui Penggunaan Media Word Wall. Alsuniyat, 1(1), 1-16. Https://Doi.Org/10.17509/Alsuniyat.V1i1.24212

Bachry, H., Yuwono, J., Pd, M., Utami, Y. T., \& Pd, M. (N.D.). Penggunaan Media Word Wall Untuk Meningkatkan Kemampuan Menulis Tegak Bersambung ( Studi Single Subject Research Pada Siswa Tunarungu Kelas III Di Skh Negeri 02 Kota Serang Banten ). 15.

Hae, Y., \& Rezeki Patricia Tantu, Y. (2021). Edukatif: Jurnal Ilmu Pendidikan Penerapan Media Pembelajaran Visual Dalam Membangun Motivasi Belajar Siswa Sekolah Dasar. Jurnal Ilmu Pendidikan, 3(4), 1177-1184. Https://Doi.Org/10.31004/Edukatif.V3i4.522

Inderasari, E., \& Agustina, T. (2017). Pembelajaran Bahasa Indonesia Pada Mahasiswa Asing Dalam Program Bipa IAIN Surakarta. Jurnal Pendidikan Bahasa Dan Sastra Indonesia, 6(2), 6-14. Https://Journal.Unnes.Ac.Id/Sju/Index.Php/Jpbsi/Article/View/20226 
2860 Penggunaan Media Pembelajaran Wordwall untuk Meniongkatkan Minat dan Motivasi Belajar Siswa pada Pembelajaran Tematik di Sekolah Dasar-Aulia Diana Devi, Subiyantoro

DOI : https://doi.org/10.31004/edukatif.v3i5.880

Kemendikbud. (2020). Surat Edaran Jendral No. 15 Tahun 2020. 09, 1-12.

Maghfiroh, K. (2018). Penggunaan Media Word Wall Untuk Meningkatkan Hasil Belajar Matematika Pada Siswa Kelas IV MI Roudlotul Huda. Jurnal Profesi Keguruan, 4(1), 65.

One, O. (2017). Efektivitas Penggunaan Media Pembelajaran Audiovisual Powtoon Dalam Meningkatkan Motivasi Belajar Siswa Di Madrasah Aliyah. Jurnal Pendidikan Dan Pembelajaran Untan, 6(3), 210239

Pranata, I. P. W., Agung, A. A. G., \& Jampel, I. N. (2021). Pengembangan Media Pembelajaran Interaktif Berbasis Articulate Storyline Pada Mata Pelajaran IPA Siswa Kelas VII. Mimbar Ilmu, 4(1), 122-130. Https://Ejournal.Undiksha.Ac.Id/Index.Php/MI/Article/View/31555

Putri, M. (2020). Efektivitas Penggunaan Aplikasi Wordwall Dalam Pembelajaran Daring (Online) Matematika Pada Materi Bilangan Cacah. UIN Syarif Hidayatullah Jakarta, 1(1), 145-165.

Rahma, F. N., Wulandari, F., Husna, D. U., Ahmad, U., \& Yogyakarta, D. (2021). Edukatif: Jurnal Ilmu Pendidikan Pengaruh Pembelajaran Daring Di Masa Pandemi Covid-19 Bagi Psikologis Siswa Sekolah Dasar. 3(5), 2470-2477.

Rohayani, F. (2020). Menjawab Problematika Yang Dihadapi Anak Usia Dini Di Masa. Qawwam: Journal For Gender Mainstreaming, 14(1), 29-50. Https://Doi.Org/10.20414/Qawwam.V14i1.2310

Saleh, A. M. (2020). Problematika Kebijakan Pendidikan Di Tengah Pandemi Dan Dampaknya Terhadap Proses Pembelajaran Di Indonesia. Jurnal Pendidikan, 2(2), 24-24.

Sari, I. K., Astuti, S., Guru, P., Dasar, S., Kristen, U., \& Wacana, S. (2021). Edukatif: Jurnal Ilmu Pendidikan Efektivitas Pembelajaran Luring Dan Daring Terhadap Hasil Belajar Tematik Siswa Di Sekolah Dasar. 3(4), 1717-1723.

Sari, P. M., \& Yarza, H. N. (2021). Pelatihan Penggunaan Aplikasi Quizizz Dan Wordwall Pada Pembelajaran Ipa Bagi Guru-Guru Sdit Al-Kahfi. 4(April), 195-199.

Suhardi, M., Albiy, R., Gistituati, N., \& Marsidin, S. (2021). Edukatif: Jurnal Ilmu Pendidikan Analisis Dampak Regulasi Pemerintah Terhadap Moda Belajar Daring Di Rumah Bagi Pelaku Pendidikan Di Madrasah Pada Masa Pandemi Covid-19. 3(4), 1849-1858.

Syah, R. H. (2020). Dampak Covid-19 Pada Pendidikan Di Indonesia: Sekolah, Keterampilan, Dan Proses Pembelajaran. Salam: Jurnal Sosial Dan Budaya Syar-I, 7(5) Https://Doi.Org/10.15408/Sjsbs.V7i5.15314

Wahyuni, H. T., Setyosari, P., \& Kuswandi, D. (2016). Implementasi Pembelajaran Tematik Kelas 1 Sd. Edcomtech, $1(2)$, $129-136$ Http://Journal2.Um.Ac.Id/Index.Php/Edcomtech/Article/Download/1799/1039 